\title{
Accounting
}

\section{The effect of ownership structure, dividend policy, composition of the board of directors on financial performance and share return}

\author{
Ida Bagus Anom Purbawangsa ${ }^{a^{*}}$ and Henny Rahyuda ${ }^{a}$
}

\begin{tabular}{|c|c|}
\hline$\overline{C H R O N I C L E}$ & A B S T RA C T \\
\hline $\begin{array}{l}\text { Article history: } \\
\text { Received March 10, } 2021 \\
\text { Received in revised format May } \\
102021 \\
\text { Accepted June } 102021 \\
\text { Available online } \\
\text { June } 112021 \\
\text { Keywords: } \\
\text { Ownership Structure } \\
\text { Performance } \\
\text { Stock Return }\end{array}$ & $\begin{array}{l}\text { The purpose of this study is to examine and analyze the direct and indirect effects of the } \\
\text { variable ownership structure, board composition, dividend policy, and financial performance } \\
\text { and stock returns in the manufacturing industry on the Indonesia Stock Exchange. The } \\
\text { population of this research is manufacturing industrial companies on the IDX since } 2015 \text { and } \\
\text { was still active until } 2019 \text {. The sample obtained is } 92 \text { issuers who continuously distribute } \\
\text { dividends. Testing the research hypothesis, using the structural equation model (SEM) with the } \\
\text { Partial Least Square (PLS) software approach. The results show that the ownership structure } \\
\text { significantly affected the composition of the board of directors and dividend policy. Ownership } \\
\text { structure has no significant effect on stock returns and financial performance. The composition } \\
\text { of the board of directors has a significant effect on dividend policy and financial performance } \\
\text { but has no significant effect on stock returns. Dividend policy has a significant effect on } \\
\text { financial performance but has no significant effect on stock returns. Financial performance has } \\
\text { no significant effect on stock returns. }\end{array}$ \\
\hline
\end{tabular}

\section{Introduction}

In public companies in Indonesia, there is no clear separation between ownership and control (Claessens et al. 2000). Most of the company's ownership structure is still concentrated by the family, and the managerial position is held by the majority shareholder or their family, as a result, what is the opinion of the largest shareholder is also the opinion of the manager. The main conflict that generally occurs in this condition is the conflict between the majority shareholder who has the most control and the minority outside shareholder. Implementation of corporate governance in companies in Indonesia is more focused on agency conflicts between majority and minority shareholders. Minority shareholder protection is one of the issues that has attracted attention in the discussion of corporate governance. La Porta et al. (2000) defines corporate governance as a set of mechanisms used by outside investors to protect themselves against expropriation by insiders. In a country with weak investor protection, control is concentrated on a few large investors. In this situation, dividends are considered as an efficient mechanism to overcome the problem of expropriation. The composition of the board of directors is also a mechanism to reduce conflicts between majority and minority shareholders. Besides influencing dividend policy and the size of the board of directors, the structure of majority and minority shareholdings may affect company performance and company stock returns.

There is a gap in previous research. The size of the board and board diversity exhibit insignificantly negative relationships with ROA in the Malaysian context, respectively. Financial leverage exhibit significantly negatively influences the Malaysian

* Corresponding author. Tel: +62 0361 - 229119

E-mail address: gidabagus@unud.ac.id (I. B. A. Purbawangsa)

(c) 2022 Growing Science Ltd. All rights reserved.

doi: $10.5267 /$ j.ac.2021.6.012 
non-financial firms. The dividend pay-out exhibits statistically significant and positive relationship with ROA in Malaysian non-financial firms, respectively. It is clearly stated that high ROAs lead the way in making good financial gains in Malaysia. However, board diversity negatively affects the ROA in Malaysian non-financial firm context because most firms are familyowned. (Tahir, 2020). The size of the board of commissioners, the board of independent commissioners and profitability affect the dividend policy, managerial ownership and liquidity do not affect the dividend policy (Yuniati et al., 2020). Another research said firms' financial performance did not produce a significant outcome (Uyar et al., 2020). The return on equity relates positively and statistically significant with the dividend yield. The firm size in the regression model revealed a negative affiliation with dividend yield variable, but it is statistically insignificant and here once again the future growth opportunity shows the negative relationship with dividend yield (Sinnarajah, 2020). La Porta et al. (2000) revealed that companies with strong governance pay higher dividends, so the outcome hypothesis predicts that there is a positive influence between the quality of corporate governance and dividend policy. On the other hand, a larger dividend substitutes for weaker governance. Thus, there is a prediction of an opposite relationship between the quality of corporate governance and dividend policy. There is an insignificant relationship between the board composition and the company's dividend policy (Abdelsalam, et al., 2008). In contrast to the results from Adjaoud and Amar (2010) where the board composition is positively related to dividend payout. Additionally, there is no clear consensus on the most suitable way to measure financial performance (Dalton and Dalton, 2011).

This study develops previous research by examining the effect of ownership structure on company stock returns through dividend policy and board composition. Ownership structures are differentiated based on majority ownership and minority ownership. Fama and Jensen (1983) stated that the separation of functions between owner and control can cause agency problems, therefore maximum regulation is needed. One form of this arrangement is through a certain ownership structure which is a dimension of corporate governance and aims to limit the movement of management steps so as to improve company performance (Gedajlovic and Shapiro, 1998). Previous research has found that ownership structure plays an important role in determining whether insiders are expropriated minority shareholders (Faccio et al., 2001; Lemmon and Lins, 2003). Expropriation of minority shareholders by majority shareholders has been widely recognized worldwide (Johnson et al., 2000; Backman, 2000; Atanasov et al., 2005; Din et al., 2021). In more detail, the terminology of corporate governance can be used to describe the roles and behaviors of the board of directors, the board of commissioners, company managers, and shareholders. The composition of the board of directors may consist of members "inside" (Inside Board) and members "outside" (outside the company concerned) to lead to the formation of an outside board. Based on this, the first hypothesis is as follows:

\section{H1: Ownership structure affects the composition of the board of directors.}

Ownership structure affects how companies attempt to protect the interests of minority investors. In a country with weak investor protection, control is concentrated on a few large investors. In this situation, dividends are considered as an efficient mechanism to overcome the problem of expropriation. Jensen and Meckling (1976); Sinnarajah (2020); Duong, et al., (2020) argue that ownership in the form of cash flow can reduce the incentive for expropriation and increase the incentive to pay dividends. Minority shareholders prefer to receive dividends rather than reinvested profits, because of the high uncertainty about whether they were duped or not. Based on this, the second hypothesis is as follows:

\section{$\mathrm{H}_{2}$ : Ownership structure affects dividend policy.}

Ownership structure also affects how the company attempts to improve financial performance. This is very reasonable because the owner has great authority to choose who will sit in management who will then determine the direction of the company's policies going forward. The paradigm adopted by many of these companies is profit-oriented. Companies that can earn large profits can be said to be successful, or have good financial performance. It is inversely proportional if the profits obtained by the company are relatively small, it can be said that the company is less successful or the performance is not good. Profitability is the end result of a number of company management policies and decisions (Brigham and Houston, 2001; Din et al., 2021). Based on this, the third hypothesis is as follows:

\section{$\mathrm{H}_{3}$ : Ownership structure affects financial performance.}

Besides influencing dividend policy, the size of the board of directors and the company's performance of the majority and minority shareholding structures may affect the company's stock returns. There is an opinion which states that the performance of a company will be influenced by who is the owner behind the company. The findings of previous studies conducted by Wang (1997), Lemmon and Lins (2001), Shahid (2003), Din et al., (2021), Adamu, et al., (2020), Hiller and McColgan (2004) found that ownership structure affects firm performance and value. Stock returns are the results obtained from stock investments. Expectations for obtaining returns also occur in financial assets. Thus investors are betting a present value for an expected value in the future. Based on this, the fourth hypothesis is as follows:

\section{$\mathrm{H}_{4}$ : Ownership structure affects stock returns.}


The composition of the board of directors is one mechanism to reduce conflict between majority and minority shareholders. One of the important motives for companies to have a board of directors is the distributive motive (limiting the interests of the majority shareholder). The distribution of dividends will make minority shareholders have additional returns apart from capital gains. Dividends also make minority shareholders have income certainty and reduce agency cost of equity due to the actions of perquisites by insiders on the company's cash flow along with decreasing monitoring costs because shareholders believe that management policies will benefit them (Crutchley and Hansen, 1989; Abbas, et al., 2021; Adamu, et al., 2020). According to van Horne (2002: 271), agency cost arises when stakeholders monitor each other. Based on this, the fifth hypothesis is as follows:

$\mathrm{H}_{5}$ : The composition of the board of directors affects dividend policy.

The composition of the board of directors is part of corporate governance which has the main objective of corporate governance is to create a control and balance system (check and balance), prevent misuse of company resources, and continue to encourage company growth. Research by Klein (1998); Yuniati, et al., (2020); Uyar, et al., (2020) concluded that there is a positive relationship between firm performance and board of directors' composition. Today, many leaders base their company performance on financial performance. Profitability is the result of several company management policies and decisions (Brigham \& Houston, 2001; Noja et al., 2021; Tahir et al., 2020b; Ngatno et al., 2021). Thus, it can be said that company profitability is the company's ability to generate net income from activities carried out in the accounting period. Based on this, the sixth hypothesis is as follows:

\section{$\mathrm{H}_{6}$ : The composition of the board of directors affects financial performance.}

The composition of the board of directors also affects the company's stock returns. Bennedsen (2000); Bawaneh (2020); Abbas et al., (2021) argues that a company will have two motives for having aboard, one of which is the governance motive (company value creation). The creation of corporate value is carried out with the board given the power to exercise corporate power. It is important to remember that the decisions of the board of directors are group decisions. Through the right decisions in management, the company is developing and increasing its corporate value. The increase in company value will be reflected by an increase in the value of the company's shares. Stock returns are expected by investors who are betting a present value for an expected value in the future. Based on this, the seventh hypothesis is as follows:

\section{$\mathrm{H}_{7}$ : The composition of the board of directors influences stock returns.}

Dividend decision concerns how much the balance between retained earnings and dividends. The company's profit can be retained or not divided (retained earnings) and can be divided so that an increase in the company's net income will increase the return on investment in the form of dividend income for investors (Brigham \& Houston, 2001; Sinnarajah, 2020; Adamu et al., 2020; Baker et al., 2020). Investors invest in the company to get a return, which consists of Yield and Capital Gain. The higher the ability to earn profits, the greater the return expected by investors, thus making the company's market performance better. Often observations show that a company with a high rate of return on investment is a company that earns a large return, it can be said to be successful or has a good performance, conversely, if the profit earned by the company is relatively small or decreases from the previous period, it can be said that the company is less successful or has poor performance. Based on this, the eighth hypothesis is as follows:

\section{$\mathrm{H}_{8}$ : Dividend policy affects financial performance.}

Dividends are part of net profit or profit after tax (earning after-tax) which is distributed to shareholders. Dividend decision concerns how much the balance between retained earnings and dividends. This decision needs to be set as optimally as possible because of the behavior of shareholders who like dividends, but there are also those who expect growth from reinvesting retained earnings in the company. If the company decides not to distribute dividends, the return on shares obtained by investors will decrease (Tahir, et al., 2020a). Tandelilin (2001: 240), from an investor's point of view, one of the important indicators to assess the prospects of a company in the future is to see the extent to which the company's profitability has grown. Based on this, the ninth hypothesis is as follows:

\section{$\mathrm{H}_{9}$ : Dividend policy affects stock returns.}

The paradigm adopted by many of these companies is profit-oriented. Companies that can earn large profits can be said to be successful, or have good financial performance. Profitability is the company's ability to generate profits (profit). This profit will be the basis for the distribution of the company's dividends, whether cash dividends or stock dividends. The company's profit can be retained or not divided (retained earnings) and can be divided so that an increase in the company's net income will increase the return on investment in the form of dividend income for investors (Brigham and Houston, 2001). Investors invest in the company to get a return, which consists of Yield and Capital Gain. The higher the ability to earn profits, the greater the return expected by investors, thus making the company's market performance better. Tandelilin (2001: 240); Nguyen, et al., (2020); Noja, et al., (2021); Uyar, et al., (2020) from an investor's point of view, one of the 
important indicators to assess the prospects of a company in the future is to see the extent to which the company's profitability has grown. Based on this, the tenth hypothesis is as follows:

$\mathrm{H}_{10}$ : Financial performance affects stock returns.

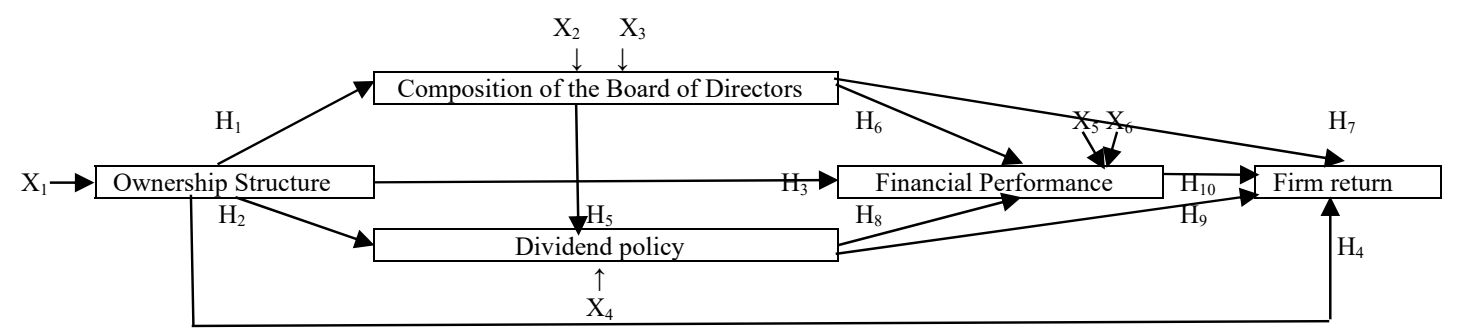

Fig. 1. Research Conceptual Framework

\section{The proposed study}

The population of this research is manufacturing industrial companies listed on the IDX since 2015 and is still active until 2019. Manufacturing companies that have been listed on the IDX from 2015 to 2019 are 153 companies. Furthermore, from the listed companies that are actively registered, there are 92 issuers that continuously distribute dividends and are used as samples in this study. The research variables consisted of 5 latent variables and 7 indicators developed using the ratio method. The research data used is historical information such as annual reports on the finances of each sample issuer. To answer research problems and to test research hypotheses, a structural equation model (SEM) is used with the Partial Least Square (PLS) software approach.

Table 1

Variable Identification

\begin{tabular}{|c|c|c|}
\hline VARIABLES & INDICATOR & HOW TO MEASURE \\
\hline Ownership Structure & Public Ownership & $\frac{\text { Proportion of the number of public shares }}{\text { Total number of shares }} \times 100 \%$ \\
\hline \multirow[t]{2}{*}{$\begin{array}{l}\text { Composition of the Board } \\
\text { of Directors }\end{array}$} & Independent Directors & $\frac{\text { Proportion of Independent Directors }}{\text { The total number of Directors }} \times 100 \%$ \\
\hline & Independent Commissioner & $\frac{\text { Proportion of Independent Commissioners }}{\text { The total number of Commissioners }} \times 100 \%$ \\
\hline Dividend Policy & Dividend per Share (DPS) & $\frac{\text { Dividend }}{\text { Total Number of Shares Outstanding }} \times 100 \%$ \\
\hline \multirow[t]{2}{*}{ Financial Performance } & Return on Asset (ROA) & $\mathrm{ROA}=\frac{\text { Profit before tax }}{\text { Total Assets }} \times 100 \%$ \\
\hline & Return on Equity (ROE) & $\mathrm{ROE}=\frac{\text { Profit before tax }}{\text { Total Capital }} \times 100 \%$ \\
\hline Stock returns & Capital Gain (Loss) & Stock returns $=\frac{P_{t}-P_{t-1}}{P_{t-1}} \times 100 \%$ \\
\hline
\end{tabular}

Source: Concepts developed in this study, 2020

The results of the structural model testing that have been formed from the problem formulation are then carried out by an outer model analysis. The tests carried out on the outer model are in several stages, namely:

Table 2

Validity Test Results with Convergent Validity

\begin{tabular}{lll}
\hline No. & Variable & Description \\
\hline 1 & $\mathrm{X}_{1}$ (Public Ownership) & The loading factor value of $1,000>0.5$, Meets Convergent Validity \\
2 & $\mathrm{X}_{2}$ (Independent Commissioner) & The loading factor value of $0,924>0,5$, Meets Convergent Validity \\
3 & $\mathrm{X}_{3}$ (Independent Directors) & The loading factor value of $0,610>0,5$, Meets Convergent Validity \\
4 & $\mathrm{X}_{4}$ (Dividend Per Share) & The loading factor value of $1,000>0,5$, Meets Convergent Validity \\
5 & $\mathrm{X}_{5}$ (Return on Asset) & The loading factor value of $0,916>0,5$, Meets Convergent Validity \\
6 & $\mathrm{X}_{6}$ (Return on Equity) & The loading factor value of $0,508>0,5$, Meets Convergent Validity \\
7 & $\mathrm{X}_{7}$ (Capital Gain/Loss) & The loading factor value of $1,000>0,5$, Meets Convergent Validity \\
\hline
\end{tabular}

Source: Data processed, 2020 
Table 3

Validity Test Results with Average Variance Extracted (AVE)

\begin{tabular}{lll}
\hline No. & Variable & Description \\
\hline 1 & Dividend Policy & AVE value of $1,000>0.5$, meets the validity test with discriminant validity \\
2 & financial performance & AVE value of $0.548>0,5$, meets the validity test with discriminant validity \\
3 & Composition of the Board of Directors & AVE value of $0.613>0,5$, meets the validity test with discriminant validity \\
4 & Stock returns & AVE value of $1.000>0,5$, meets the validity test with discriminant validity \\
5 & Ownership Structure & AVE value of $1.000>0,5$, meets the validity test with discriminant validity \\
\hline Source $:$ Data processed, 2020 &
\end{tabular}

Based on the table of validity test results, it shows that the concept of the measured variable fulfills the validity test. In addition to the validity test, a reliability test was also carried out by looking at the Composite Reliability value and strengthened by the Cronbach Alpha value, the Cronbach alpha value above 0.60 means good, and above 0.30 is sufficient.

Table 4

Reliability Test Results with Composite Reliability

\begin{tabular}{lll}
\hline No. & Variable & Description \\
\hline 1 & Dividend Policy & The value of Composite Reliability 1.000 $>0,60$, reliability is good \\
2 & financial performance & The value of Composite Reliability $0.691>0,60$, reliability is good \\
3 & Composition of the Board of Directors & The value of Composite Reliability $0.752>0,60$, reliability is good \\
5 & Stock returns & The value of Composite Reliability $1.000>0,60$, reliability is good \\
\hline
\end{tabular}

Source: Data processed, 2020

Table 5

Reliability Test Results with Cronbach's Alpha

\begin{tabular}{lll}
\hline No. & Variable & Description \\
\hline 1 & Dividend Policy & Cronbach's Alpha value of $1,000>0.60$, reliability is good \\
2 & financial performance & Cronbach's Alpha value of $0.212>0,20$, sufficient reliability \\
3 & Composition of the Board of Directors & Cronbach's Alpha value of $0.413>0,20$, sufficient reliability \\
4 & Stock returns & Cronbach's Alpha value of $1.000>0,60$, reliability is good \\
5 & Ownership Structure & Cronbach's Alpha value of $1.000>0,60$, reliability is good \\
\hline
\end{tabular}

Source: Data processed, 2020

Tests carried out on the overall predictive relevance model based on the PLS measurement results are seen from the R Square Output results shown in Table 6.

Table 6

Goodness of fit model results with R Square

\begin{tabular}{ll}
\hline Variable & Description \\
\hline Dividend Policy & $R$ Square $0.053>0$, has predictive relevance \\
financial performance & $R$ Square $0.160>0$, has predictive relevance \\
Composition of the Board of Directors & $R$ Square $0.649>0$, has predictive relevance \\
Stock returns & $R$ Square $0.010>0$, has predictive relevance \\
\hline
\end{tabular}

Source: Data processed, 2020

The results of hypothesis testing based on the output of the PLS program can be seen in Table 7.

The first hypothesis is to test the relationship between the ownership structure variable on the composition of the board of directors, the results in the table show the t-statistic value of 16.72. The measurement results show the t-statistic value of $16.72>1.96$ (5\% significance level) with the original sample value of 0.80 , so the first hypothesis in this study is accepted. These data indicate that the sample data on the ownership structure variable is successful in showing evidence of its relationship with the variable composition of the board of directors. This means that if there is an increase in the quality of the ownership structure, there will be an increase in the quality of the composition of the board of directors, this effect has a high significance. The ownership structure which is dominated by the public influences the consideration of the board of directors to maximize its performance which is centered on two motives, namely the governance motive (company value creation) and the distributive motive (reducing the interests of the majority shareholder) (Bennedsen, 2000). The results of this study also support agency theory because this study shows that the bigger and more complex the company, the better agents are needed to control the company. 
Table 7

Goodness of fit model results with R Square

\begin{tabular}{|c|c|c|c|c|c|}
\hline Effect & $\begin{array}{l}\text { Original } \\
\text { Sample } \\
\text { (O) }\end{array}$ & $\begin{array}{l}\text { Sample } \\
\text { Mean } \\
(\mathrm{M})\end{array}$ & $\begin{array}{l}\text { Standard } \\
\text { Deviation } \\
\text { (STDEV) }\end{array}$ & $\begin{array}{l}\text { T Statistics } \\
(|\mathrm{O} / \mathrm{STDEV}|)\end{array}$ & Description \\
\hline Ownership Structure $\rightarrow$ Board of Directors Composition & 0.806 & 0.819 & 0.048 & 16.723 & Significant \\
\hline Ownership Structure $\rightarrow$ Dividend Policy & -0.381 & -0.404 & 0.146 & 2.612 & Significant \\
\hline Ownership Structure $\rightarrow$ Financial Performance & -0.044 & -0.043 & 0.106 & 0.417 & Not significant \\
\hline Ownership Structure $\rightarrow$ Stock Return & -0.048 & -0.047 & 0.059 & 0.806 & Not significant \\
\hline Composition of the Board of Directors $\rightarrow$ Dividend Policy & 0.352 & 0.378 & 0.123 & 2.863 & Significant \\
\hline Board of Directors Composition $\rightarrow$ Financial Performance & -0.142 & -0.153 & 0.067 & 2.113 & Significant \\
\hline Board of Directors Composition $\rightarrow$ Stock Return & -0.018 & -0.019 & 0.040 & 0.435 & Not significant \\
\hline Dividend Policy $\rightarrow$ Financial Performance & -0.402 & -0.404 & 0.116 & 3.483 & Significant \\
\hline Dividend Policy $\rightarrow$ Stock Return & -0.032 & -0.029 & 0.057 & 0.563 & Not significant \\
\hline Financial Performance $\rightarrow$ Stock Return & 0.080 & 0.070 & 0.128 & 0.625 & Not significant \\
\hline
\end{tabular}

Source: Data processed, 2020

The second hypothesis is to test the relationship between the variable ownership structure on dividend policy, the results in Table 6 show the t-statistic value of $2.61<1.96$ (significance level of $5 \%$ ) with the original sample value of -0.381 then the second hypothesis in this study was accepted. This data shows that the sample data on the ownership structure variable succeeds in showing evidence of its relationship with the dividend policy variable. This means that if there is an increase in the quality of the ownership structure with an increase in independent directors and independent commissioners, then the dividend policy taken will be better and this effect has a high significance. This study further supports the results of research conducted by Crutchley and Hansen (1989) that minority shareholders make dividends as an effort to obtain income certainty and agency cost of equity due to the actions of investors who also work in the company. So the more public investors who own the company's shares, the more dividends the company will pay for its investors. The results of this study are different from the results of research conducted by Wei et al., (2003) which found a significant negative relationship between public ownership and stock dividends. Because Wei's research found that minority shareholders do not have the incentive and ability to collect information and monitor management. The third hypothesis is to test the relationship between ownership structure variables on financial performance, the results in the table show a t-statistic value of 0.417 . The measurement results show the $t$-statistic value of $0.417<1.96$ (significance level of $5 \%$ ) with the original sample value (original sample) -0.005 . The results of empirical testing of the third hypothesis are rejected because although there is a positive or unidirectional relationship between the ownership structure and financial performance, the effect is not real or significant. Companies that can earn large profits can be said to be successful or have good financial performance. Profitability is the result of a number of company management policies and decisions in managing company finances (Brigham \& Houston, 2001). The fourth hypothesis is to test the relationship between ownership structure variables on stock returns, the results in the table show a tstatistic value of 0.85 . The measurement results show the t-statistic value of $0.806<1.96$ ( $5 \%$ significance level), so the fourth hypothesis in this study is rejected. These data indicate that the sample data on the ownership structure variable does not show evidence of its relationship with the stock return variable. This means that if the stock return variable has an influence on the ownership structure, but it is not significant or there is no significant effect. This indicates that the ownership structure variable is not a determining factor for the stock return variable. The fifth hypothesis is to test the relationship between the variable composition of the board of directors on dividend policy, the results in the table show a t-statistic value of 2.86 . The measurement results show the t-statistic value of 2.86>1.96 (5\% significance level), so the fifth hypothesis in this study is accepted. This data shows that the sample data on the composition of the board of directors has shown evidence of its relationship with the dividend policy variable. This means that if there is an increase in the quality of the composition of the board of directors, there will be an increase in the quality of dividend policy taken by the company, this influence has a high significance. The composition of the board of directors as measured by indicators of independent commissioners and independent directors will control so that the company does not run based solely on the interests of insiders but also pays attention to public investors, which of course this decision will improve the quality of dividend policy taken by the company. Bennedsen (2000) argues that a company will have two motives for having a board, namely (1) a governance motive (company value creation), (2) a distributive motive (limiting the interests of the majority shareholder).

The sixth hypothesis is to test the relationship between the variable composition of the board of directors on financial performance, the results in the table show the t-statistic value of 2.11. The measurement results show the t-statistic value of $2.11>1.96$ (5\% significance level), so the sixth hypothesis in this study is accepted. These data indicate that the sample data on the composition of the board of directors has shown evidence of its relationship with financial performance variables. This means that if there is an increase in quality in the composition of the board of directors, there will be an increase in the company's financial performance, this influence has a high significance. Bennedsen (2000) argues that a company will have two motives for having aboard, one of which is (1) a governance motive (company value creation). The creation of good corporate value is the goal of the company in carrying out capital management and a form of corporate performance appraisal. So the better the composition of the board of directors, with representatives from qualified outer investors, can improve the performance of companies that are assessed by ROA and ROE that focus on the level of income from managing the company's capital and assets. The seventh hypothesis is to test the relationship between the variable composition of the board of directors 
on stock returns, the results in the table show a t-statistic value of 0.44 . The measurement results show the t-statistic value of $0.44<1.96(5 \%$ significance level), so the seventh hypothesis in this study is rejected. These data indicate that the sample data on the composition of the board of directors does not show evidence of its relationship with the stock return variable. This means that if there is an increase in quality in the composition of the board of directors, the return on shares owned by the company will increase but not significantly because there is no significant effect. Dividend payments will be a monitoring tool as well as bonding for insiders (Copeland and Weston, 1992: 568). The distribution of dividends will make minority shareholders have additional returns apart from capital gains. Dividends also make minority shareholders have income certainty and reduce agency cost of equity due to the actions of perquisites by insiders on the company's cash flow along with decreasing monitoring costs because shareholders believe that management policies will benefit them (Crutchley and Hansen, 1989). The eighth hypothesis is to test the relationship between dividend policy variables on financial performance, the results in the table show the t-statistic value of 3.48. The measurement results show the t-statistic value of $3.48>1.96(5 \%$ significance level), so the eighth hypothesis in this study is accepted. This data shows that the sample data on the dividend policy variable has successfully shown evidence of its relationship with financial performance variables. This means that if there is an increase in the quality of the dividend policy decisions taken, there will be an increase in the company's financial performance, this influence has a high significance. The ninth hypothesis is to test the relationship between dividend policy variables on stock returns, the results in the table show a t-statistic value of 0.50 . The measurement results show the t-statistic value of $0.563<1.96(5 \%$ significance level), so the ninth hypothesis in this study is rejected. These data indicate that the sample data on the dividend policy variable does not show evidence of its relationship with the stock return variable. This means that if there is an increase in the quality of the dividend policy taken, then the stock returns owned by the company will experience a direct or positive change but not really, because there is no significant effect. The tenth hypothesis is to test the relationship between financial performance variables on stock returns, the results in the table show a t-statistic value of 0.63 . The measurement results show the t-statistic value of $0.625<1.96$ ( $5 \%$ significance level), so the tenth hypothesis in this study is rejected. These data indicate that the sample data on financial performance variables are not successful in showing evidence of their relationship with the stock return variable. This means that if there is an increase in the quality of the financial performance taken, then the stock returns owned by the company will change directionally but not significantly because there is no significant effect. If the company performs well by doing efficiently, managing assets and capital appropriately. Then the greater the profits obtained by the company. The company's financial statements will clearly show that the more companies perform well, the greater the profits obtained, the company's stock returns which also come from profits will increase.

\section{Conclusion}

The purpose of this study is to examine and analyze the direct and indirect influence of the variable ownership structure, board composition, dividend policy and financial performance, and stock returns in the manufacturing industry on the Indonesia Stock Exchange. The test results do not support all the hypotheses proposed. Ownership structure has a significant positive effect on the composition of the board of directors and dividend policy, but not on financial performance and stock returns. The composition of the board of directors has a significant effect on dividend policy and financial performance, but on stock returns, the relationship is not significant. Meanwhile, dividend policy has a positive and significant effect on financial performance, but on stock returns, it has a positive but insignificant effect. Finally, there is financial performance on stock returns which has a positive but insignificant effect. The results of this study support agency theory and signaling theory. The capital market presents the economic conditions of a country. The more advanced and developed a country's capital market is, the more advanced and developing the country's economy is, and vice versa. Investor protection is very important because investor protection encourages capital market development. When investors are protected from expropriation, they will be willing to pay more expensive securities.

\section{References}

Abbas, U., Farooq, M. I., Kashif, A. R., Hassan, S., \& Scholar, S. M. P. (2021). Effect Of Dividend Paying Behavior And Board Size And Board Composition On Firm's Performance: Evidence From Pakistan. Academy Of Accounting And Financial Studies Journal, 25(2), 1-17.

Abdelsalam, O., El-Masry, A., \& Elsegini, S. (2008). Board composition, ownership structure and dividend policies in an emerging market: Further evidence from CASE 50. Managerial Finance, 34(12), 953-964

Adamu, A. I., Ekundayo, O., \& Bala, H. (2020). Does Size Of The Firm Matter In The Relationship Between Foreign Ownership And Dividend Policy? Malaysian Management Journal, 24, 1-18.

Adjaoud, F., \& Ben-Amar, W. (2010). Corporate Governance And Dividend Policy: Shareholders' Protection Or Expropriation?. Journal Of Business Finance \& Accounting, 37, 648-667. Https://Doi.Org/10.1111/J.14685957.2010.02192.X

Atanasov, V. (2005). How much value can blockholders tunnel? Evidence from the Bulgarian mass privatization auctions. Journal of Financial Economics, 76(1), 191-234.

Baker, H. K., Dewasiri, N. J., Premaratne, S. P., \& Koralalage, W. Y. (2020). Corporate Governance And Dividend Policy In Sri Lankan Firms: A Data Triangulation Approach. Qualitative Research In Financial Markets, 12(4), 543-560. 
Bawaneh, S. S. (2020). Impact Of Corporate Governance On Financial Institutions? Performance: A Board Composition Case. Asian Economic And Financial Review, 10(1), 54.

Bennedsen, M. (2000). Political ownership. Journal of Public Economics. 76(3), 559-581.

Brigham, E. F. and Houston, J. F. (2011). Manajemen Keuangan. Jakarta: Erlangga.

Claessens, S., Djankov, S. and Lang, L. H. P. (2000). The separation of ownership and control in East Asian corporations. Journal of financial Economics, 58(1-2), 81-112.

Copeland, T. E., Weston, J. F., \& Shastri, K. (1988). Financial theory and corporate policy. Addison-Wesley Reading, MA

Crutchley, C. E., \& Hansen, R. S. (1989). A test of the agency theory of managerial ownership, corporate leverage, and corporate dividends. Financial Management, 18(4), 36-46.

Dalton, D. R., \& Dalton, C. M. (2011). Integration Of Micro And Macro Studies In Governance Research: Ceo Duality, Board Composition, And financial Performance. Journal Of Management, 37(2), 404-411 00000.

Din, S. U., Khan, M. A., Khan, M. J., \& Khan, M. Y. (2021). Ownership Structure And Corporate Financial Performance In An Emerging Market: A Dynamic Panel Data Analysis. International Journal Of Emerging Markets.

Duong, D. K., Phan, T. T. P., Pho, K. H., \& Mcaleer, M. (2020). Impact Of Board Characteristics And State Ownership On Dividend Policy In Vietnam. Advances In Decision Sciences, 24(4), 1-34.

Faccio, M., Lang, L. H. P., \& Young, L. (2001). Dividends and expropriation. American Economic Review, 91(1), pp. $54-78$.

Fama, E. F., \& Jensen, M. C. (1983). Separation of ownership and control. The journal of law and Economics, 26(2), $301-325$.

Gedajlovic, E. R., \& Shapiro, D. M. (1998). Management and ownership effects: Evidence from five countries. Strategic Management Journal, 19(6), 533-553.

Horne, J. C. Van and John M. Wachowicz, J. (2008). Fundamentals of Financial Management. 13th ed. Pearson Education.

Jensen, M. C. and Meckling, W. H. (1976). Theory of the firm: managerial behavior, agency cost and ownership structure. Journal of Financial Economics, 3, 305-360. doi: 10.1016/0304-405X(76)90026-X

Johnson, S., La Porta, R., Lopez-de-Silanes, F., \& Shleifer, A. (2000). Tunneling. American Economic Review, 90(2), 22-27.

La Porta, R., Lopez-de-Silanes, F., Shleifer, A., \& Vishny, R. W. (2000). Agency problems and dividend policies around the world. The Journal of Finance, 55(1), 1-33.

Ngatno, Apriatni, E. P., \& Youlianto, A. (2021). Moderating Effects Of Corporate Governance Mechanism On The Relation Between Capital Structure And Firm Performance. Cogent Business \& Management, 8(1), 1866822.

Nguyen, T. H. H., Ntim, C. G., \& Malagila, J. K. (2020). Women On Corporate Boards And Corporate Financial And NonFinancial Performance: A Systematic Literature Review And Future Research Agenda. International Review Of Financial Analysis, 101554.

Noja, G. G., Thalassinos, E., Cristea, M., \& Grecu, I. M. (2021). The Interplay Between Board Characteristics, Financial Performance, And Risk Management Disclosure In The Financial Services Sector: New Empirical Evidence From Europe. Journal Of Risk And Financial Management, 14(2), 79.

Sinnarajah, S. (2020). The Impact Of Ownership Structure On Dividend Policy Of Listed Companies In Srilanka: With Special Reference To The Banks Finance And Insurance Sector. Global Journal Of Management And Business Research, 20(3).

Tahir, H., Hussain, S., Iqbal, A., Aslam, E., \& Masri, R. (2020). Determinants Of Return On Assets Of Non-Financial Firm Of Malaysia.

Tahir, H., Masri, R., \& Rahman, M. (2020). Determinants Of Dividend Pay-Out Policy Of Listed Non-Financial Firms In Malaysia. International Journal Of Financial Research, 11(2), 68-76.

Uyar, A., Kilic, M., Koseoglu, M. A., Kuzey, C., \& Karaman, A. S. (2020). The Link Among Board Characteristics, Corporate Social Responsibility Performance, And Financial Performance: Evidence From The Hospitality And Tourism Industry. Tourism Management Perspectives, 35, 100714.

Yuniati, R., Wijayanti, A., \& Dewi, R. R. (2020). The Effect Of Corporate Governance And Financial Performance On Dividend Policy. Jasa (Jurnal Akuntansi, Audit Dan Sistem Informasi Akuntansi), 4(3), 436-448.

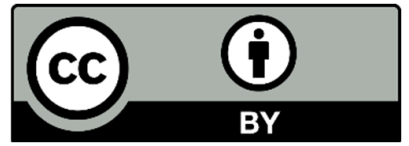

(C) 2022 by the authors; licensee Growing Science, Canada. This is an open access article distributed under the terms and conditions of the Creative Commons Attribution (CC-BY) license (http://creativecommons.org/licenses/by/4.0/). 